\title{
Isolation and Characterization of a Generalized Transducing Phage for the Marine Luminous Bacterium Vibrio fischeri MJ-1
}

\author{
By REUBEN LEVISOHN, † JAY MORELAND AND K. H. NEALSON* \\ University of Wisconsin-Milwaukee, Center for Great Lakes Studies, 600 E. Greenfield Ave., \\ Milwaukee, WI 53204, USA
}

(Received 29 October 1986; revised 28 January 1987)

\begin{abstract}
A marine bacteriophage active against the marine luminous bacterium Vibrio fischeri $\mathrm{MJ}-1$ was isolated from offshore waters in Ensenada, Baja California, Mexico, and was shown to be active in generalized transduction, transducing 14 of 17 different amino acid auxotrophs to prototrophy. For some of the amino acid auxotrophic markers, such as arginine and methionine, several different mutants could be transduced. The phage grew well at temperatures up to $27^{\circ} \mathrm{C}$, and produced high-titre lysates $\left(10^{10}\right.$ p.f.u. $\mathrm{ml}^{-1}$ or higher). Single-step growth analysis showed a latent period of $23 \mathrm{~min}$ at $25^{\circ} \mathrm{C}$ with a burst size of 100 . Phage adsorption was maximum at $\mathrm{NaCl}$ concentrations characteristic of the marine environment. No evidence for lysogeny was found.
\end{abstract}

\section{INTRODUCTION}

Phages attacking marine bacteria have been known for many years (ZoBell, 1946), but only relatively recently have detailed studies of their host range, physiology, structure and genetics been reported. Methods for the isolation and quantification of phages active against several different groups of marine bacteria have been published (Hidaka, 1971; Moebus, 1980; Koga et al., 1982). The phages have been characterized by their host ranges (Valentine \& Chapman, 1966; Moebus \& Nattkemper, 1981), their ionic requirements (Spencer, 1960; Chen et al., 1966; Nakamura et al., 1978) and their fine structure (Valentine et al., 1966; Sklarow et al., 1973; Torella \& Morita, 1979). Only a few genetic studies have been reported (Baross et al., 1973; Keynan et al., 1974), the latter presenting evidence for a specialized transducing phage active in transducing tryptophan auxotrophs of the marine luminous bacterium Vibrio harveyi to prototrophy. This phage was subsequently used to prepare a fine-structure genetic map of the $V$. harveyi tryptophan operon (Crawford \& Nelson, 1976; I. P. Crawford \& C. Beiger, unpublished).

The luminous bacterium Vibrio fischeri strain MJ-1 was originally isolated from the light organ of the luminous fish Monocentris japonicus (Ruby \& Nealson, 1976). Recently the genes for bioluminescence from this strain were cloned and expressed in Escherichia coli (Engebrecht et al., 1983), indicating that the lux genes, which code for the components necessary for luminescence, are located on a single contiguous area of the bacterial chromosome. Further studies have shown that the lux regulon consists of two operons that code for a total of seven proteins (Engebrecht \& Silverman, 1984).

Other than cloning and expression of cloned genes in $E$. coli, no genetic studies have been reported in $V$. fischeri. For this reason, we initiated a search for bacteriophages that might be useful for genetic mapping purposes in strain $M J-1$. We report here the isolation and characterization of a generalized transducing phage, $\mathrm{rp}-1$, which has been used to transduce several different auxotrophs to prototrophy.

† Permanent address: Department of Microbiology, Tel-Aviv University, Tel Aviv, Israel. 


\section{METHODS}

Growth of bacteria and isolation of phage. Strain MJ-1 was isolated from the light organ of the luminous fish Monocentris japonicus and identified as Vibrio fischeri (Ruby \& Nealson, 1976). Several other strains of this species were also tested for phage sensitivity: CG-1 and CG-6, isolated from the light organs of two different specimens of the luminous fish Cleidopus gloriamaris; Y-1, a strain that emits yellow light (Ruby \& Nealson, 1977); the type strain of $V$. fischeri (ATCC 7744); and 22 seawater isolates of $V$. fischeri obtained from coastal waters near Israel ( 12 from the Mediterranean Sea, 2 from the Red Sea, 8 from the hypersaline Bardawil Lagoon). All cultures were grown and maintained on SWC medium, consisting of $5 \mathrm{~g}$ Difco Bacto-Peptone, $0.5 \mathrm{~g}$ Difco Yeast Extract and $3 \mathrm{ml}$ glycerol in 1 litre of $75 \%(\mathrm{v} / \mathrm{v})$ seawater (Nealson, 1978). For experiments in minimal media, an artificialseawater based medium, BGM, was used as previously described (Nealson, 1978). This medium contains, per litre of distilled water: $15.5 \mathrm{~g} \mathrm{NaCl} ; 0.75 \mathrm{~g} \mathrm{KCl} ; 12.4 \mathrm{~g} \mathrm{MgSO}_{4} .7 \mathrm{H}_{2} \mathrm{O} ; 1.45 \mathrm{~g} \mathrm{CaCl}_{2} .2 \mathrm{H}_{2} \mathrm{O} ; 50 \mathrm{ml}$ Tris buffer stock (1 M, pH 7.5); $0.028 \mathrm{~g} \mathrm{FeSO}_{4} .7 \mathrm{H}_{2} \mathrm{O} ; 0.075 \mathrm{~g} \mathrm{~K}_{2} \mathrm{HPO}_{4} .3 \mathrm{H}_{2} \mathrm{O} ; 1 \mathrm{~g} \mathrm{NH} \mathrm{NH}_{4} ; 3 \mathrm{ml}$ glycerol.

Stock cultures were maintained on agar media $\left(1.5 \%, \mathrm{w} / \mathrm{v}\right.$, Difco Bacto-agar) at $20^{\circ} \mathrm{C}$. Phages were grown and titrated by standard dilution methods in SWC $0.6 \%(\mathrm{w} / \mathrm{v})$ top agar. These were done with $0.2 \mathrm{ml}$ of exponentialphase bacteria plus $0.1 \mathrm{ml}$ of the appropriate serial dilution of phage added to $4 \mathrm{ml}$ of soft agar. After gentle mixing, these were poured over fresh SWC agar plates and incubated at room temperature (about $25^{\circ} \mathrm{C}$ ). Plaques were easily visible after $10-12 \mathrm{~h}$.

Phage rp-1 was isolated from a sample of highly polluted seawater collected in August 1983 in the port of Ensenada, Baja California, Mexico. Yeast extract and peptone were mixed with the sample (200 ml) to make up SWC medium, and $1.5 \mathrm{ml}$ of exponential-phase $\mathrm{MJ}-1$ cells was added. This enrichment was shaken at room temperature for several hours. A lysate obtained by addition of $0 \cdot 1$ vol. chloroform was tested against strain $\mathrm{MJ}-1$ and shown to contain $10^{9}$ p.f.u. $\mathrm{ml}^{-1}$. A pure strain of the phage was obtained by repeated isolation of single plaques from soft agar.

Phage preparation. Small-volume phage stocks were prepared by confluent lysis of plates containing approximately $10^{3}$ plaques. Phage were washed off the plates in $5 \mathrm{ml}$ sterile seawater, mixed vigorously on a vortex mixer, and centrifuged $(8000 \mathrm{~g}, 10 \mathrm{~min})$ to remove bacterial cells and debris. The supernatants were then collected and stored over 0.1 vol. chloroform at $4{ }^{\circ} \mathrm{C}$. Titres of about $2 \times 10^{10}$ p.f.u. $\mathrm{ml}^{-1}$ were obtained by this method. Alternatively, $10^{6}$ phage were inoculated on a soft agar $(0.4 \%$, w/v) lawn of MJ-1. After overnight growth, the lawn was harvested with a spatula, mixed with 0.1 vol. chloroform, and centrifuged directly. High-titre largevolume phage stocks were prepared by inoculating an SWC liquid culture of $\mathrm{MJ}-1$ containing approximately $1.5 \times 10^{8}$ cells $\mathrm{ml}^{-1}$ with phage rp-1 at a final concentration of $10^{4}$ p.f.u. $\mathrm{ml}^{-1}$ and aerating until lysis occurred. Using this method, titres in excess of $3 \times 10^{10} \mathrm{ml}^{-1}$ were obtained; the stocks were then concentrated by highspeed centrifugation $(35000 \mathrm{~g}, 1 \mathrm{~h})$.

One-step growth experiments were performed according to Adams (1959). One $\mathrm{ml}$ of a rapidly growing culture $\left(5 \times 10^{7}\right.$ cells $\left.\mathrm{ml}^{-1}\right)$ of $\mathrm{MJ}-1$ was mixed with $1 \times 10^{7}$ phage particles. After adsorption $(5 \mathrm{~min})$ this mixture $(10 \mu \mathrm{l})$ was diluted in $200 \mathrm{ml} \mathrm{SWC}$ medium in a $500 \mathrm{ml}$ Erlenmeyer flask, and gently shaken at $25^{\circ} \mathrm{C}$. At $2 \mathrm{~min}$ intervals, two samples $(0.1 \mathrm{ml})$ were removed and assayed for p.f.u.

Auxotrophs. Auxotrophic mutants of MJ-1 were isolated after treatment with $N$-methyl- $N^{\prime}$-nitro- $N$ nitrosoguanidine (MNNG) (Sigma). Overnight cultures were washed twice in sterile seawater, resuspended in sea water at a concentration of $10^{9}$ cells $\mathrm{ml}^{-1}$ and allowed to stand (room temperature, $1 \mathrm{~h}$ ). A small crystal of MNNG was then added, and at intervals $(10 \mathrm{~min}), 30 \mathrm{SWC}$ plates were spread with $0.1 \mathrm{ml}$ of a $10^{4}$ dilution of the mutagenized cells so that at $1 \%$ survival the plates yielded 100 colonies per plate. Using this approach, mutagenesis of the surviving colonies was excellent, and several auxotrophs could be picked from each plate by replica plating to SWC and BGM plates. The auxotrophs were identified by replica plating to BGM plates containing mixtures of amino acids.

Transduction. Exponentially growing cultures of auxotrophic mutants (about $5 \times 10^{8} \mathrm{cells}^{-1}$ ) were infected with phages that had been irradiated with UV light to $1 \%$ survival. An m.o.i. of 3 (assayed before irradiation) was used for maximum transduction. Phages were adsorbed ( $8 \mathrm{~min}$, room temperature) and $5 \times 10^{7}$ bacteria were plated directly on BGM. Controls containing phage and recipient bacteria individually were also plated. Colonies were counted after incubation for 3-4 $\mathrm{d}$ at room temperature.

Electron microscopy. A drop of seawater containing rp-1 ( $>10^{12}$ p.f.u. $\left.\mathrm{ml}^{-1}\right)$ was placed on a carbon-coated grid, dried, washed twice with distilled water, negatively stained with $2 \%(w / v)$ uranyl acetate, and then used directly for electron microscopy as previously described (Keynan et al., 1974).

DNA extraction. DNA was extracted and precipitated from rp-1 according to Maniatis et al. (1982), with the exception that the chloroform extraction step was omitted. After storage at $-20^{\circ} \mathrm{C}$, samples were centrifuged $(9000 \mathrm{~g}, 40 \mathrm{~min})$, and the pellets lyophilized for several minutes until visibly dry. These were then resuspended in TE buffer ( $10 \mathrm{mM}$-Tris/ $\mathrm{HCl}, \mathrm{pH} 5 \cdot 0,1 \mathrm{mM}$-EDTA), incubated at $65^{\circ} \mathrm{C}$ for $10 \mathrm{~min}$ and mixed on a vortex mixer to ensure complete recovery. These stocks were stored at $-20^{\circ} \mathrm{C}$. 


\section{Table 1. Characteristics of bacteriophage rp-1}

Shape and size*

$s_{20, w}$ of phage $\dagger$

Density of phaget

DNAt

Adsorption time

Burst time

Burst size

Host range (strains sensitive/ strains tested) $\ddagger$
Head: appears hexagonal; probably icosohedral; $83 \mathrm{~nm}$ diameter

Tail: long, straight, contractile; length $83 \mathrm{~nm}$; width $16 \mathrm{~nm}$

852

$1.525 \mathrm{~g} \mathrm{ml}^{-1}$

$48 \mathrm{MDa}$

$>95 \%$ in $5 \mathrm{~min}$

$23 \mathrm{~min}$ at $25^{\circ} \mathrm{C}$

100 p.f.u. per bacterium infected

E. coli, $0 / 4 ; V$. harveyi, $0 / 46 ; V$. cholerae, $0 / 1$;

$V$. splendida, $0 / 2 ; V$. fischeri, $21 / 27 ;$ Xenorhabdus luminescens, $0 / 3$;

Photobacterium phosphoreum, 0/9; Photobacterium leiognathi, 0/19;

Alteromonas hanedai, $0 / 1$

\footnotetext{
* Size estimates are means of six measurements of intact phage particles of known magnification. For intact phage, sizes were reproducible to within $5 \%$.

† Phage density and $s_{20, w}$ determinations were done by preparative density-gradient centrifugation of whole phage, and analytical density-gradient centrifugation of DNA, respectively, as described by Keynan et al. (1974). DNA size was estimated by agarose gel electrophoresis with known standards (Maniatis et al., 1982).

$\ddagger$ Droplets of $2 \mu \mathrm{l}$ containing a total of $2 \times 10^{6} \mathrm{p}$.f.u. of phage rp-1 were spotted onto freshly prepared lawns of bacteria to be tested, in fresh, soft-agar overlays. Lysis was visually checked after $1 \mathrm{~d}$ incubation at room temperature.
}

\section{RESULTS AND DISCUSSION}

The isolation of $\mathrm{rp}-1$ was unusually difficult in comparison to many of the phage isolations we have previously done. Many attempts were made on a variety of different samples off Southern California, where $V$. fischeri is known to occur in abundance (Ruby \& Nealson, 1977). The reasons for this are not known. Similar attempts off the coast of Israel yielded $V$. fischeri phages relatively easily.

\section{Characteristics of phage $r p-1$}

The host range and other general characteristics of rp-1 are shown in Table 1. Many strains of marine bacteria were tested for sensitivity to phage $\mathrm{rp}-1$, including Vibrio harveyi, Photobacterium phosphoreum, Photobacterium leiognathi, Alteromonas hanedai, and several nonluminous species. Only strains of $V$. fischeri were sensitive, and of 27 strains tested, 21 were sensitive to rp-1. The non-sensitive strains included CG-1, CG-6, Y-1 and ATCC 7744 as well as one strain each from the Mediterranean Sea and the Red Sea. All other $V$. fischeri isolates tested were sensitive to lysis by phage rp-1.

One criterion that has been used to characterize marine phages is that of specific ionic requirements (Spencer, 1960), and although rp-l was isolated from the marine environment and is specific for a marine bacterial host, it differs markedly from other marine phages with respect to ionic stability. Even in distilled water, where other marine phages are lysed within minutes (Keynan et al., 1974) rp-1 was stable for $24 \mathrm{~h}$. Although inactivation did not occur with changes in ionic strength, phage adsorption was affected (Fig. 1). Adsorption was maximum at $3 \%(\mathrm{w} / \mathrm{v})$ $\mathrm{NaCl}$, near the total salinity of seawater, and decreased rapidly at either higher or lower $\mathrm{NaCl}$ concentrations.

Although rp-1 was stable at temperatures of $35^{\circ} \mathrm{C}$ and below, it was rapidly inactivated by temperatures of $45^{\circ} \mathrm{C}$ or greater. Temperature also affected plaque morphology; at $23^{\circ} \mathrm{C}$, plaques were clear (or slightly hazy) with well-defined edges. At $30^{\circ} \mathrm{C}$, plaques formed, but they were very opaque (hazy) with poorly defined edges. In some cases the centres of these plaques had clear zones.

Fig. 2 shows the effect of phage infection on growth and luminescence of strain $\mathrm{MJ}-1$; there was no significant effect on light emission until cell lysis occurred. In no case was it possible to show lysogeny of MJ-1 by rp-1. Supernatants of phage-resistant cultures were screened by the soft-agar overlay method, and they carried no phage. 

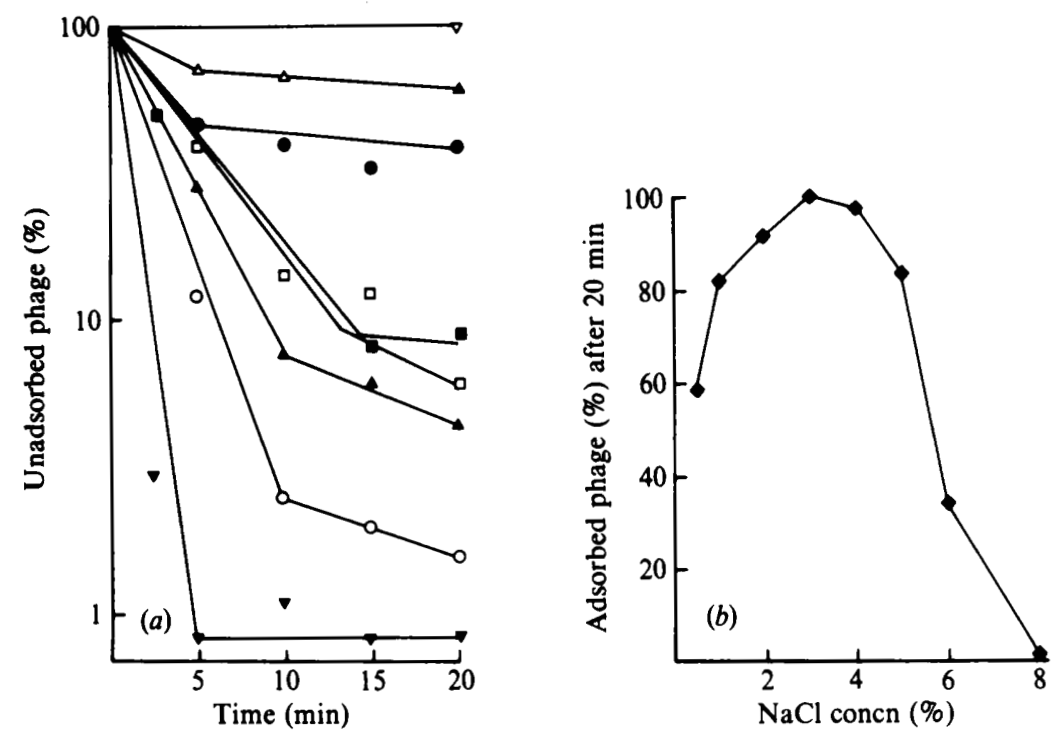

Fig. 1. An exponential-phase culture of $\mathrm{MJ}-1\left(1.5 \times 10^{8}\right.$ cells $\left.\mathrm{ml}^{-1}\right)$ was harvested by centrifugation and resuspended at the same density in distilled water containing $\mathrm{NaCl}$ at various concentrations. Phage rp-1 was added to these suspensions at an m.o.i. of 0.05 . At the indicated times samples were removed, shaken with chloroform and subsequently titrated to determine the phages not removed by adsorption to the bacteria. $\mathrm{NaCl}$ concentrations $(\%, w / v): \nabla, 8 ; \triangle, 6 ; \square, 5 ; 0,4 ; \nabla, 3 ; \Delta, 2 ; \square, 1$; $0,0.5$.

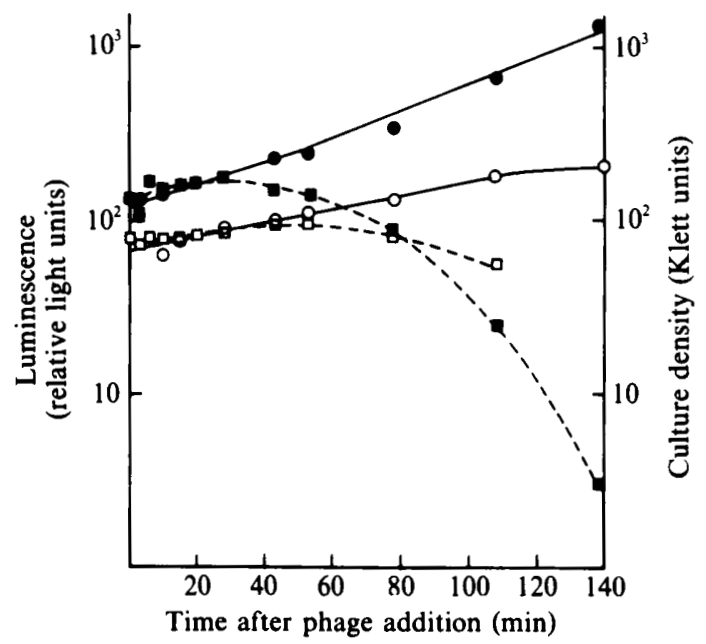

Fig. 2. An exponential-phase culture of MJ-1 $\left(1.5 \times 10^{8}\right.$ cells $\left.\mathrm{ml}^{-1}\right)$ at $23^{\circ} \mathrm{C}$ was divided into two portions, and phage $\mathrm{rp}-1$ was added to one $(\square, \square)$ at an m.o.i. of 3 . At the indicated times, culture density $(O, \square)$ and bioluminescence $(O, \square)$ were monitored. Luminescence measurements were done according to Ruby \& Nealson (1977).

\section{Transduction experiments}

With the advent of molecular genetic approaches, the search for transducing phages and other more classical genetic alternatives might well be questioned. However, in systems such as the marine bacteria, alternative genetic systems, such as transducing phages, are of potentially great value. Part of this value lies in the fact that there are aspects of the physiology and regulation of 
Table 2. Transduction of MJ-1 auxotrophs by phage rp-1 grown on wild-type MJ-1

\begin{tabular}{|c|c|c|c|c|c|}
\hline $\begin{array}{c}\text { Mutant } \\
\text { designation* }\end{array}$ & Revertants $\dagger$ & Transductants $\dagger$ & $\begin{array}{c}\text { Mutant } \\
\text { designation }\end{array}$ & Revertants $\dagger$ & Transductants $\dagger$ \\
\hline arg-2 & 0.0 & 40 & leu-3 & 0.0 & 12 \\
\hline $\arg -4$ & $10 \cdot 0$ & 37 & lys -1 & 0.7 & 56 \\
\hline asn-1 & $2 \cdot 7$ & 35 & met-1 & $10 \cdot 0$ & 49 \\
\hline cys -1 & 0.0 & 30 & met-2 & $11 \cdot 0$ & 40 \\
\hline cys -3 & 0.3 & 41 & met-5 & $42 \cdot 0$ & 96 \\
\hline cys -4 & 0.7 & 43 & thi-I & $1 \cdot 3$ & 27 \\
\hline cys -6 & $1 \cdot 0$ & 36 & thr-I & 0.0 & 23 \\
\hline$g l y-3$ & 0.3 & 13 & trp-2 & 4.0 & 29 \\
\hline his-2 & $4 \cdot 3$ & 45 & tyr-1 & $4 \cdot 0$ & 40 \\
\hline ile-2 & 0.0 & 11 & tyr-2 & 0.3 & 106 \\
\hline$i l v-3$ & $0 \cdot 3$ & 29 & & & \\
\hline
\end{tabular}

* No transductants were obtained for the following mutants: arg- $1,-3,-5,-6,-7 ;$ cys- $2,-5 ;$ gln- $1,-2 ;$ leu- $1,-2,-4$; met-3, -4 ; orn-1; pro-1, -2 .

$\dagger$ Numbers are the mean of three experiments, and represent the number of revertants or transductants per $5 \times 10^{7}$ infected recipients plated.

Table 3. Transduction of MJ-1 mutants by rp-1 grown on auxotrophs

$\begin{array}{cc}\begin{array}{c}\text { Mutant } \\ \text { transduced }\end{array} & \text { Revertants* } \\ \text { arg-2 } & 0.0 \\ \text { arg-5 } & 0.0 \\ \text { asn-1 } & 2 \cdot 3 \\ \text { cys-4 } & 2.7 \\ \text { cys-6 } & 3 \cdot 7 \\ \text { lys-1 } & 0.0 \\ \text { trp-2 } & 2 \cdot 7 \\ \text { tyr-2 } & 0.0\end{array}$

\begin{tabular}{cccc}
\multicolumn{4}{c}{ Transductants* with phage grown on: } \\
\hline Wild-type & arg- & $c y s-6$ & $t y r-2$ \\
18 & 0.0 & 30 & 26 \\
$0 \cdot 3$ & 0.0 & 0.0 & 0.3 \\
54 & 55 & 15 & 103 \\
48 & 28 & 0.0 & 72 \\
39 & 18 & 3.7 & 53 \\
74 & 57 & 54 & 17 \\
29 & 28 & 20 & 59 \\
103 & 75 & 106 & 0.3
\end{tabular}

* Numbers are the mean of three experiments, and represent the number of revertants or transductants per $5 \times 10^{7}$ infected recipients plated.

the luminous system that differ between $E$. coli and naturally luminous bacteria, so that a complete understanding of the luminous system will depend on studies done in strains from which the genes were obtained. For example, in $\mathrm{MJ}-1$, luminescence is strongly repressed by iron, while no iron repression of luminescence is seen with the cloned genes in $E$. coli (Haygood \& Nealson, 1985).

Table 2 is a compilation of transduction experiments done using phage rp-1 prepared on wildtype MJ-1 cells. Of 38 different auxotrophic isolates, 21 were transduced to prototrophy; these included 14 of 17 different markers, with several positives for some markers. Transduction efficiencies varied by about a factor of 10 between mutants, with the best efficiency shown by tyr-2. This mutant also had a low reversion rate and was thus the mutant of choice for further experiments. All transductants tested remained sensitive to phage rp-1 and none released any detectable phage into the medium.

Several other experiments were done in order to test the hypothesis that the increased reversal to prototrophy was indeed due to transduction. Phage lysates used for transduction were tested for the presence of live bacteria by streaking onto SWC plates. None were found, ruling out the possibility of contamination or conjugation. Treatment of rp-1 lysates with pancreatic DNAase under conditions which led to maximum hydrolysis of calf thymus DNA had no effect on the ability of these lysates to transduce, ruling out the possibility of transformation. Finally, an rp-1resistant mutant of $t y r-2$, which showed no adsorption of phage $\mathrm{rp}-1$, was not reverted to prototrophy by exposure to rp-1.

Table 3 shows the results of transduction experiments using phage preparations grown on 
several different auxotrophic strains. In no case was it possible to transduce an auxotrophic mutant with phage grown on that strain. Mutant $c y s-4$ was transduced by phage grown on three other auxotrophs, but not by phage grown on either $c y s-4$ or $c y s-6$ auxotrophs, suggesting that these mutations were identical or very closely linked.

No wide-host-range plasmids have yet been successfully transformed into and maintained in strain MJ-1. The availability of $\mathrm{rp}-1$, which clearly replicates well in $\mathrm{MJ}-1$, opens the possibility of engineering its DNA for use as a genetic vector in this strain. Until this report, no generalized transducing phages had been reported for $V$. fischeri. The success obtained in transducing auxotrophs with phages grown on a variety of different mutants suggests that the phage could be used for genetic studies including fine-structure mapping. Such studies would nicely complement other methods of genetic analysis.

This work was done while R. L. was on sabbatical leave from Tel Aviv University. It was supported in part from grants to K.H.N. from the Office of Naval Research (N00014-80-C0066) and from the Milwaukee Foundation.

This publication is no. 295 from the Center for Great Lakes Studies.

\section{REFERENCES}

ADAMS, M. H. (1959). The Bacteriophages. New York: Wiley-Interscience.

Baross, J. A., Liston, J. \& Morita, R. Y. (1973). Some implications of genetic exchange among marine vibrios, including Vibrio parahaemolyticus, naturally occuring in the Pacific oyster. In International Symposium on Vibrio parahaemolyticus, pp. 129-137. Tokyo: Saikon Publishing Co.

Chen, P. K., Citarella, R. V., Salazar, O. \& Colwell, R. R. (1966). Properties of two marine bacteriophages. Journal of Bacteriology 91, 11361139.

Crawford, I. P. \& Nealson, K. H. (1976). The tryptophan genes and enzymes of a marine luminous bacterium. Federation Proceedings 35, 1546.

Engebrecht, J. \& Sil verman, M. (1984). Identification of genes and gene products necessary for bacterial bioluminescence. Proceedings of the National Academy of Sciences of the United States of America 81, 4145-4158.

Engebrecht, J., Nealson, K. H. \& Silverman, M. (1983). Bacterial bioluminescence: isolation and genetic analysis of functions from Vibrio fischeri. Cell 32, 773-781.

HaygoOD, M. G. \& Nealson, K. H. (1985). Mechanisms of iron regulation of luminescence in Vibrio fischeri. Journal of Bacteriology 162, 209-216.

HIDAKA, T. (1971). Isolation of marine bacteriophages from seawater. Bulletin of the Japanese Society of Scientific Fisheries 37, 1199-1206.

Keynan, A., Nealson, K. H., Sideropoulos, H. \& Hastings, J. W. (1974). Marine transducing bacteriophage attacking a luminous bacterium. Journal of Virology 14, 333-340.

Koga, T., Toyoshima, S. \& Kawata, T. (1982). Morphological varieties and host ranges of Vibrio parahaemolyticus bacteriophages isolated from seawater. Applied and Environmental Microbiology 44, 466-470.

Maniatis, T., Fritsch, E. \& SambrooK, J. (1982). Molecular Cloning: a Laboratory Manual. Cold Spring Harbor, NY: Cold Spring Harbor Laboratory.

MoEbus, K. (1980). A method for the detection of bacteriophages from ocean water. Helgoländer Meeresuntersuchungen 34, 1-14.

Moebus, K. \& NaTtKemPer, H. (1981). Bacteriophage sensitivity patterns among bacteria isolated from marine waters. Helgoländer Meeresuntersuchungen 34, 375-385.

Nakamura, K., Kakimoto, D., Swafford, J. \& JoHNSON, R. (1978). Studies of the characteristics of the bacteriophages of Vibrio alginolyticus strain B-1 isolated from Kinko Bay. Memoirs of the Faculty of Fisheries, Kagoshima University 27, 59-64.

NEALSON, K. H. (1978). Isolation, identification and manipulation of luminous bacteria. Methods in Enzymology 57, 153-156.

Ruby, E. G. \& Nealson, K. H. (1976). Symbiotic association of Photobacterium fischeri with the luminous fish Monocentris japonica: a model of symbiosis based on bacterial studies. Biological Bulletin 151, 574-586.

Ruby, E. G. \& Nealson, K. H. (1977). A luminous bacterium which emits yellow light. Science 196, 432-435.

Sklarow, S. S., Colwell, R. R., Chapman, G. B. \& ZAN, S. F. (1973). Characteristics of a Vibrio parahaemolyticus bacteriophage isolated from Atlantic coast sediment. Canadian Journal of Microbiology 19, 1519-1520.

SPENCER, R. (1960). Indigenous marine bacteriophages. Journal of Bacteriology 79, 614.

TORella, R. \& Morita, R. Y. (1979). Evidence by electron micrographs for a high incidence of bacteriophage particles in the waters of Yaquina Bay, Oregon: ecological and taxonomical implications. Applied and Environmental Microbiology 37, 774-778.

Valentine, A. F. \& Chapman, G. B. (1966). Fine structure and host-virus relationship of a marine bacterium and its bacteriophage. Journal of Bacteriology 92, 1535-1554.

Valentine, A. F., Chen, P. K., Colwell, R. R. \& Chapman, G. B. (1966). Structure of a marine bacteriophage as revealed by negative staining techniques. Journal of Bacteriology 91, 819-822.

ZoBell, C. E. (1946). Marine Microbiology. Waltham, Mass.: Chronica Botanica Co. 